\title{
Evaluation of the Safety of Commonly Sold Yoghurts in UYO Metropolis
}

\author{
Idongesit Abel Clement ${ }^{1}$, Moses Bassey Ekong ${ }^{1 *}$ and Joseph Udo Idiong ${ }^{2}$ \\ ${ }^{1}$ Department of Anatomy, Faculty of Basic Medical University of Uyo, Uyo, Nigeria \\ ${ }^{2}$ Department of Physiology, Faculty of Basic Medical University of Uyo, Uyo, Nigeria
}

\begin{abstract}
Yogurt is an important nutritional diary product consumed in different forms by people irrespective of age, sex and socioeconomic status. However, reports of food poisoning often associated with its consumption lead to this research which aimed at evaluating the safety of the commonly consumed yogurt brands in Uyo Metropolis of Nigeria. Several sachets of frozen yoghurt from 14 different brands were collected randomly at different locations in Uyo Metropolis in Nigeria. These samples were allowed to thaw, and aseptically aspirated for microbiological analysis, detection of Escherichia coli (E. coli), gram staining, and antimicrobial susceptibility tests. Results show that $E$. coli was isolated from four (4) brands (29\%) of the samples, and all the detected $E$. coli were gram negative rods. The isolated $E$. coli were susceptible to peflacin, streptomycin, ofloxacin, ciprofloxacin and augmentin. Some of the $E$. coli were however resistant to nalidixic acid, gentamycin, septrin, ceporex, while all the samples were resistant gentamicin, septrin and ampicillin. In conclusion, the results of this study demonstrate that Uyo Metropolis is at serious risk of $E$. coli infection because of its isolation from some finished yoghurt products in circulation, and which could be resistant to some commonly used antibiotics.
\end{abstract}

Keywords: Yogurt; Uyo metropolis; Escherichia coli; Gram negativity; Antibiotics

\section{Introduction}

Yoghurt is a milk product made from bacterial fermentation of milk. The process of fermentation of yoghurt involves the conversion by the bacteria of lactose in the milk to lactic acid. This lactic acid acts on the milk protein to give the yoghurt the thick and sour presentation. The first step in yoghurt preparation is heating the milk to $80^{\circ} \mathrm{C}$ to kill any bacteria present and to denature the milk protein so that they set together instead of becoming curds. After, it is cooled to $45^{\circ} \mathrm{C}$, then a bacteria culture is added and the milk is kept at that temperature for 4 to 8 hours to allow the fermentation process to take place [1-3]. Since yoghurts have sour taste, they are often sweetened or flavored with vanilla, honey, fruits, among others [4]. Steins [5] reported that unsweetened yoghurts were the healthiest for diabetics. The yoghurt made with low fat or fat free milk were reported to be more beneficial, while the yoghurt made with sugar substitute was reported to be healthier than sweetened yoghurt or yoghurt containing real sugar [6].

It is reported that yoghurt unlike milk is well- tolerated by lactose-intolerant individuals [7]. It enhances the immune response by increasing the percentage of $\mathrm{B}$ lymphocytes and the phytohemaglutamin and lipopolysaccharide induced proliferative responses of Peyer's patches in the intestine [8]. It is also reported to reduce the risk of high blood pressure [9]. However, often times there are general diagnosis of food poisoning after yoghurt consumption. Most of the time this is due to the presence of bacteria with Escherichia coli ( $E$. coli) being top on the list, as E. coli infections are mostly attributed to diary food products from animals [10-13]. E. coli are gram-negative bacteria commonly found in the intestines of birds and mammals. Only a small subset of this group of bacteria such as E. coli strain O157 is pathogenic to humans. E. coli infections are disseminated by foods, water and person-to-person contact and even milk products [14]. Thus, consumption of yoghurts may predispose one to E. coli infections [15-17]. This research is aimed at evaluating the safety of the commonly consumed yoghurt within Uyo metropolis against E. coli contamination.

\section{Materials and Methods}

The following techniques were applied; microbiological analysis, detection of $E$. coli, gram staining for gram positivity or gram negativity, and antimicrobial susceptibility test. Several sachets of frozen yoghurt processed from 14 different companies with different product names were collected randomly at different locations in Uyo Metropolis in Nigeria. These samples were allowed to thaw, and aseptically aspirated with the aid of micro pipette. They were transferred to sterile test tubes containing $9 \mathrm{ml}$ of distilled water to make stock solutions. From the stock solutions, 5 fold dilutions of different samples were obtained. That is, a millilitre of the solution of samples in test tube A (stock) was aspirated into another test tube (B) containing $9 \mathrm{ml}$ of distilled water. This process was repeated three (3) more times into test tubes $\mathrm{C}, \mathrm{D}$ and $\mathrm{E}$ respectively. With the aid of a wire loop thoroughly sterilized over Bunsen burner flame, and allowed to cool, the last samples of each yoghurt dilutions were picked and inoculated on plates of Mc conkey Agar and were incubated for 24 hours at $32^{\circ} \mathrm{C}$. Bacteria were grown and colonies were formed.

The samples that contained bacterial growth were aseptically transferred using a sterilized wire loop from the Mc conkey Agar plate to properly labelled clean grease-free slides containing a drop of distilled water. The slides were spread into a thin area approximately and were allowed to air-dry completely. They were then quickly passed over a flame of Bunsen burner. The smears on the slides were flooded with crystal violet for one minute and were rinsed in tap water. The slides were then flooded with iodine for one minute, then rinsed in tap

*Corresonding author: Moses Bassey Ekong, Department of Anatomy, Faculty of Basic Medical University of Uyo, Uyo, Nigeria, Tel: +2348030868505; E-mail: mbe_flashpoint@yahoo.com

Received October 05, 2015; Accepted October 29, 2015; Published November 10, 2015

Citation: Clement IA, Ekong MB, Idiong JU (2015) Evaluation of the Safety of Commonly Sold Yoghurts in UYO Metropolis. J Food Process Technol 7: 532. doi:10.4172/2157-7110.1000532

Copyright: (c 2015 Clement IA, et al. This is an open-access article distributed under the terms of the Creative Commons Attribution License, which permits unrestricted use, distribution, and reproduction in any medium, provided the original author and source are credited. 
water and with $95 \%$ ethyl alcohol for one minute to decolorize, and then were rinsed again in running tap water. The slides were flooded with saffranin for 45 seconds and were washed with tap water, and were kept in a slant position to air-dry. Oil immersion was applied in to view them microscopically. Samples that contained bacteria were picked and were sub-cultured on nutrient agar as well. That is, transferring some cell from the previous culture medium to a fresh growth medium. Antibiotic sensitivity disk were introduced into the plates and the bacteria were incubated for another 24 hours against the following antibiotics; tarivid (ofloxation), ciprofloxacin, peflacin, augmentin, gentamycin, streptomycin, ceporex, nalidixic acid, septrin, and ampicillin. These processes were carried out on weekly basis for a month.

\section{Results}

Analytical results of the commonly sold yoghurt showed that of a total number of fourteen (14) different brands of yoghurt samples evaluated, E. coli were isolated from four (4) brands, representing $29 \%$ of the samples. All the detected E. coli were gram negative rods.

The E. coli isolated were susceptible to the following common antibiotics; peflacin, streptomycin, ofloxacin, ciprofloxacin and augmentin. Some of the E. coli were however resistant to nalidixic acid, gentamycin, septrin, ceporex, and were all resistant gentamicin, septrin and ampicillin

\section{Discussion}

Yoghurt which has always been considered safe because of its intrinsic nature is reported to be involved in fatal infections [1517]. The presence of $E$. coli as a contaminant in this dairy product is reported as one of the major cause of food poisoning, and since this diary product is widely sold in Uyo Metropolis, this motivated the need for this study on its safety from E. coli. The result of this study showed that $E$. coli was detected in four ( $29 \%$ of the samples) different yoghurt brands from different companies, and their karyotyping showed all to be gram negative. It is reported that $E$. coli survives in dairy products such as yoghurt and colby, romano and feta cheeses, among others for several weeks [18]. This may be due to inadequate processing procedure. The present study is in line with the work of Adetunji and Arigbede [19] who reported the presence of $E$. coli in finished yoghurt products, which they attributed to the failure in the processing stages and the subsequent survival of the organisms throughout processing. This result may also be attributed to post processing contamination at the production site or from secondary users that distribute such. Dineen et al. [12] reported that even low levels of E. coli can cause the contamination of these finished dairy products.

Testing of the susceptibility of the E. coli to common antibiotics in the present study showed that the E. coli in the yoghurt samples were susceptible to peflacin, streptomycin, ofloxacin, ciprofloxacin, augmentin. However, some of the samples were resistant to nalidixic acid, gentamicin, septrin and ceporex, though all the samples were resistant gentamicin and septrin. Most bacteria develop intrinsic resistances to some antibiotics. These bacteria show resistance to such antibiotics like tetracycline, vancomycin, erythromycin, streptomycin, clindamycin, gentamicin, oxacillin and lincosamide [20]. While pasteurization will kill all $E$. coli bacteria, thermization may not kill all the E. coli, though no pathogenic E. coli will survive [21]. Alhelfi et al. [22] reported that contaminated milk, whether raw or pasteurized, allow the proliferation of $E$. coli $\mathrm{O} 157$ at room temperature. Massa et al. [23] also reported that storing contaminated raw milk at $8^{\circ} \mathrm{C}$, for
1-2 weeks allows E. coli $\mathrm{O} 157$ to survive and even proliferate, which is usually considered the main cause of haemorrhagic colitis, which may lead to severe other diseases and death in humans [13,24-28]. Thus, the $\mathrm{pH}$ and temperature usually determine the presence or absence of these bacteria as the outbreak of $E$. coli is tolerant to acidic conditions, particularly at lower temperatures [29-31].

\section{Conclusion}

The results of this study demonstrates that Uyo Metropolis and beyond are at serious risk of $E$. coli infection because of its isolation from some finished yoghurt products in circulation, and which could be resistant to some commonly used antibiotics.

\section{References}

1. Tamime AY, Deeth HC (1980) Yoghurt: Technology and Biochemistry. Journal of Food Protection 43: 939-977.

2. Ross RP, Morgan S, Hill C (2002) Preservation and fermentation: Past, present and future. International Journal of Food Microbiology 79: 3-16.

3. Lahtinen S, Ouwehand AC, Salminen S, Von Wright A (2012) Lactic Acid Bacteria: Microbiological and Functional Aspects. CRC Press (Tayor and Francis Group), Boca Raton.

4. Askdrsears (2006) Live cultures in yogurt.

5. Steins N (2015) High protein snacks for diabetics.

6. Ipatenco $S(2015)$ Is sugar in yogurt bad for you?

7. Kolars JC, Levitt MD, Aouji M, Savaiano DA (1984) Yogurt - an autodigesting source of lactose. New England Journal of Medicine 310: 1-3.

8. Mazahreh AS, Ershidat OTM (2009) The benefits of lactic acid bacteria in yogurt on the gastrointestinal function and health. Pakistan Journal of Nutrition 8: $1404-1410$.

9. Park KM, Cifelli CJ (2013) Dairy and blood pressure: A fresh look at the evidence. Nutrition Reviews 71: 149-157.

10. Riley LW, Remis RS, Helgerson SD, McGee HB, Wells JG, et al. (1983) Hemorrhagic colitis associated with a rare Escherichia coli serotype 0157:H7. New England Journal of Medicine 308: 681-685.

11. Adams M, Mitchell R (2002) Fermentation and pathogen control: A risk assessment approach. International Journal of Food Microbiology 79: 75-83.

12. Dineen SS, Takeuchi K, Soudah JE, Boor KJ (1998) Persistence of Escherichia coli $0157: \mathrm{H} 7$ in dairy fermentation systems. Journal of Food Protection 61 1602-1608.

13. Elder RO, Keen JE, Siragusa GR, Barkocy-Gallagher, Koohmaraie M, et al (2000) Correlation of enterohemorrhagic Escherichia coli O157:H7 prevalence in feces, hides, and carcasses of beef cattle during processing. Proceedings of the National Academy of Science 7: 2999-3003.

14. Griffin PM, Tauxe RV (1991) The epidemiology of infections caused by Escherichia coli $\mathrm{O} 157: \mathrm{H} 7$, other enterohemorrhagic $E$. coli and the associated hemolytic uremic syndrome. Epidemiology Reviews, 13: 60-98.

15. Morgan D, Nawman CP, Hutchinson DN, Walkes AM, Rowe B, et al. (1993) Verotoxin-producing Escherichia coli O157:H7 infections associated with the consumption of yoghurt. Epidemiology and Infection 111: 181-187.

16. Mead PS, Slutsker L, Dietz V, McCaig LF, Bresee PM, et al. (1999) Foodrelated illness and death in the United States. Emerging Infectious Diseases 5: 607-625.

17. Gulmez M, Guven A (2003) Survival of Escherichia coli O157:H7, Listeria monocytogenes $4 \mathrm{~b}$ and Yersinia enterocolitica $\mathrm{O} 3$ in different yogurt and kefir combinations as prefermentation contaminant. Journal of Applied Microbiology 95: 631-636.

18. Hudson LM, Chen J, Hill AR, Griffiths MW (1997) Bioluminescence: A rapid indicator of Escherichia coli 0157:H7 in selected yoghurt and cheese varieties. Journal of Food Protection 60: 891-897.

19. Adetunji VO, Arigbede MI (2011) Occurrence of E. coli O157:H7 and Listeria 
Citation: Clement IA, Ekong MB, Idiong JU (2015) Evaluation of the Safety of Commonly Sold Yoghurts in UYO Metropolis. J Food Process Technol 7: 532. doi:10.4172/2157-7110.1000532

Page 3 of 3

monocytogenes and identification of hazard analysis critical control points (HACCPs) in production operations of a typical tropic cheese 'wara' and yoghurt. Pakistan Journal of Nutrition 10: 796-804

20. Ashraf R, Shah NP (2011) Antibiotic resistance of probiotic organisms and safety of probiotic dairy products. International Food Research Journal 18: 837-853.

21. Peng S, Hummerjohann J, Stephan R, Hammer P (2013) Heat resistance of escherichia coli strains in raw milk at different subpasteurization conditions. Journal of Dairy Science 96: 3543-3546.

22. Alhelfi NA, Lahmer RA, Jones DL, Williams AP (2012) Survival and metabolic activity of luxmarked Escherichia coli O157:H7 in different types of milk. The Journal of Dairy Research 79: 257-261.

23. Massa S, Goffredo E, Altieri C, Natola K (1999) Fate of Escherichia coli O157:H7 in unpasteurized milk stored at 8 degrees c. Letters in Applied Microbiology 28: 89-92.

24. Su C, Brandt LJ (1995) Escherichia coli 0157 infection in humans. Annals of Internal Medicine 123: 698-707.

25. Baars T (2013) Milk consumption, raw and general, in the discussion of health or hazard. Nutritional Ecology and Food Research 1: 91-107.
26. Bourdichon F, Casaregola S, Farrokh C, Frisvad JC, Gerds ML, et al. (2012) Food fermentations: microorganisms with technological beneficial use. International Journal of Food Microbiology 154: 87-97.

27. Gaggia F, Di Gioia D, Baffoni L, Biavati B (2011) The role of protective and probiotic cultures in food and feed and their impact in food safety. Trends in Food Science and Technology 22: 58-66.

28. Gest HH (2004) The discovery of microorganisms by Robert Hooke and Anton van Leeuwenhoek, Fellows of The Royal Society. Notes and Records of the Royal Society of London 58: 187-201.

29. Gillespie IA, Adak GK, O'Brien SJ, Bolton FJ (2003) Milk borne genera outbreaks of infectious intestinal disease, England and Wales, 1992-2000. Epidemiology and Infection 130: 461-468.

30. Kim YB, Okuda J, Matsumoto C, Morigaki T, Asai NW, Nichibuchi MH (1999) Isolation of an Escherichia coli $\mathrm{O} 157: \mathrm{H} 7$ strain producing shiga toxin 1 but not shiga toxin 2 from patient with hemolytic uremic syndrome in Korea. FEMS Microbiology 166: 43-48.

31. Weagent SD, Bryant JL, Bark DH (1994) Survival of Escherichia coli O157:H7 in mayonnaise and mayonnaise-based sauce at room and refrigerated temperatures. Journal of Food Protection 57: 629-631. 